\title{
In vitro inhibition of canine distemper virus by flavonoids and phenolic acids: Implications of structural differences for antiviral design
}

\author{
O.V. Carvalho ${ }^{\text {a }}$, C.V. Botelho ${ }^{\text {a }}$, C.G.T. Ferreira ${ }^{\text {a }}$, H.C.C. Ferreira ${ }^{a}$, M.R. Santos ${ }^{a}$, M.A.N. Diaz ${ }^{\text {b }}$, T.T. Oliveira ${ }^{\text {b }}$, \\ J.A.P. Soares-Martins ${ }^{c}$, M.R. Almeida ${ }^{b}$, A. Silva Júnior ${ }^{\text {a,* }}$ \\ a Laboratório de Virologia Animal (LVA), Departamento de Veterinária, Universidade Federal de Viçosa, Viçosa, MG, Brazil \\ ${ }^{\mathrm{b}}$ Departamento de Bioquímica e Biologia Molecular, Universidade Federal de Viçosa, Viçosa, MG, Brazil \\ ${ }^{\mathrm{c}}$ Medical College of Wisconsin, Department of Microbiology and Molecular Genetics, Milwaukee, WI, USA
}

\section{A R T I C L E I N F O}

\section{Article history:}

Received 19 July 2012

Accepted 8 April 2013

\section{Keywords:}

Canine distemper

Antiviral activity

Flavonoids

Phenolic acids

\begin{abstract}
A B S T R A C T
Infection caused by canine distemper virus (CDV) is a highly contagious disease with high incidence and lethality in the canine population. Antiviral activity of flavonoids quercetin, morin, rutin and hesperidin, and phenolic cinnamic, trans-cinnamic and ferulic acids were evaluated in vitro against the CDV using the time of addition assay to determine which step of the viral replicative cycle was affected. All flavonoids displayed great viral inhibition when they were added at the times 0 (adsorption) and $1 \mathrm{~h}$ (penetration) of the viral replicative cycle. Both quercetin and hesperidin presented antiviral activity at the time $2 \mathrm{~h}$ (intracellular). In the other hand, cinnamic acid showed antiviral activity at the times 0 and $2 \mathrm{~h}$ while trans-cinnamic acid showed antiviral effect at the times $-1 \mathrm{~h}$ (pre-treatment) and $0 \mathrm{~h}$. Ferulic acid inhibited CDV replicative cycle at the times 0 and $1 \mathrm{~h}$. Our study revealed promising candidates to be considered in the treatment of CDV. Structural differences among compounds and correlation to their antiviral activity were also explored. Our analysis suggest that these compounds could be useful in order to design new antiviral drugs against CDV as well as other viruses of great meaning in veterinary medicine.
\end{abstract}

(c) 2013 Elsevier Ltd. All rights reserved.

\section{Introduction}

Canine distemper is caused by a single stranded RNA virus of the genus Morbillivirus, family Paramyxoviridae. In dogs, canine distemper virus (CDV) can result in gastrointestinal and/or respiratory clinical signs, often accompanied by neurological signs (Martella et al., 2008). Although there are commercial vaccines against canine distemper, the disease remains one with the highest incidence and lethality in dogs (Rodeheffer et al., 2007). The virus has been reported in wild animals (ferrets, wild dogs, foxes, coyotes, hyenas, lions, tigers, leopards, seals, sea lions and dolphins) (Appel et al., 1994; Kennedy, 1998; Murphy et al., 1999; Moro et al., 2004). The domestic dog is most commonly infected, and although the disease has been also found in big cats, the domestic cat is not susceptible (Martella et al., 2008).

Currently, therapeutic studies for CDV have employed either synthetic inhibitors that interfere with morbillivirus replication (Scagliarini et al., 2006; White et al., 2007; Elia et al., 2008; Yoon et al., 2008; Dal Pozzo et al., 2010) or natural compounds that

* Corresponding author. Address: Laboratório de Virologia Animal, Departamento de Veterinária, Universidade Federal de Viçosa, Avenida Peter Henry Rolfs, s/n Campus Universitário, 36570-000 Viçosa, MG, Brazil. Tel.: +55 313899 1471; fax: +55313899 1457 .

E-mail address: abelardo.junior@ufv.br (A. Silva Júnior). display anti-CDV activity in vitro at early and/or late stages of viral replication (Gallina et al., 2011; Bagla et al., 2012).

Phenolic compounds are plant secondary metabolites widely distributed among plant species and are targets of great scientific interest due to their pharmacological properties and therapeutic value (Schnitzler et al., 2008). The compounds have antioxidant, anti-allergic, anti-inflammatory, anti-mutagenic, anticarcinogenic and antibacterial effects (Shon et al., 2004; Nafisi et al., 2008; Orhan et al., 2010; Shimosaki et al., 2011). Flavonoids and phenolic acids, two major phenolic groups, have been reported to inhibit the replication of many viruses (Rees et al., 2008; Saha et al., 2009; Kim et al., 2010; Gravina et al., 2011).

The antiviral activity of the flavonoid quercetin ( $3^{\prime}, 4,3,5,7$-pentahydroxil flavonol) has been reported for some viruses, including adenovirus 3 (AdV-3), herpes simplex virus (HSV) and influenza virus (Choi et al., 2009; Thapa et al., 2011). Morin (2',4'3,5,7-pentahydroxil flavonol), another flavonoid, had antiviral action against equine herpesvirus 1 (EHV-1) (Gravina et al., 2011). Antiviral activity of glycosidic flavonoids was shown by rutin (quercetin-3-Orutinoside) against HSV, dengue virus 2 (DENV-2) and human immunodeficiency virus (HIV) (Tao et al., 2007; Zandi et al., 2011), and hesperidin against influenza virus (Saha et al., 2009).

Both cinnamic acid and its trans isomers are phenolic acids or intermediate compounds in the synthesis routes of flavonoids 
(Yadav et al., 2008). Phenolic acids have been reported to have antiviral effects against DENV, EHV-1 and HIV (Ichimura et al., 1999; Rees et al., 2008; Gravina et al., 2011).

Some studies correlate changes in the structure of flavonoids with changes in their biological mechanisms. According to Kim et al. (2010), isoquercetin, a glycosylated form of quercetin, showed higher inhibitory activity against influenza virus in vitro and in vivo than that reported for quercetin. Another study by Thapa et al. (2011) investigated the synthesis and antiviral activity of various derivatives of quercetin with hydroxyl substitutions at C-3, C-3' and C-5; synthetic analogs of quercetin demonstrated therapeutic index for influenza virus greater than that of quercetin.

Given the high impact of canine distemper disease upon the canine population as well as the lack of a specific antiviral treatment, the goal of the present work was to investigate natural compounds and their antiviral activity against CDV. We evaluated the in vitro inhibition of the CDV replicative cycle by the flavonoids quercetin, morin, rutin and hesperidin, and the phenolic acids cinnamic, trans-cinnamic and ferulic acids. Implications regarding structural differences of compounds and correlation with their antiviral activity were also considered.

\section{Materials and methods}

\subsection{Cells and viruses}

Vero cells were maintained in minimal essential medium (MEM) supplemented with $10 \%$ fetal bovine serum (SBF), penicillin $(1.6 \mathrm{mg} / \mathrm{L})$ and streptomycin $(0.4 \mathrm{mg} / \mathrm{L})$ at $37{ }^{\circ} \mathrm{C}$ and $5 \% \mathrm{CO}_{2}$. Canine distemper virus (strain Rockborn, 11th passage) was titrated by determining the infective dose for $50 \%$ tissue culture $\left(\mathrm{TCID}_{50}\right)$, according to the method described by Reed and Muench (1938).

\subsection{Compounds}

All seven phenolic compounds (quercetin, morin, rutin, hesperidin, cinnamic acid, trans-cinnamic acid and ferulic acid) were purchased from Sigma-Aldrich (Deisenhofen, Germany) (Figs. 8 and 9). Compounds were initially dissolved in dimethylsulfoxide (DMSO) to a stock concentration of $10 \mathrm{mg} / \mathrm{mL}$ and stored at $4{ }^{\circ} \mathrm{C}$. When needed, compounds were diluted in MEM at the time of use to provide working concentrations.

\subsection{Cytotoxicity assays}

The cytoxicity of the phenolic compounds was determined by microscopic evaluation searching for changes in cell viability and morphology. Non-toxic concentrations were also confirmed by a variation of the colorimetric method based on reduction of the salt 3-(4,5-dimethylthiazol-2-yl)-2,5-diphenyltetrazolium bromide (MTT) (Sigma-Aldrich, Deisenhofen, Germany) by mitochondrial enzymes described by Mosmann (1983). Briefly, Vero cells were seeded into 96 -well microplates, and after four hours at $37{ }^{\circ} \mathrm{C}$ different concentrations of each compound were added into media and analyzed after $72 \mathrm{~h}$. Effect on cell morphology was observed microscopically, then cells were washed twice with phosphate buffered saline (PBS) pH 7.2 and incubated with MTT solution (1 mg/ $\mathrm{mL}$ ) for four hours. Subsequently, the formed salt was dissolved by adding DMSO (100 mL/well) followed by shaking for $15 \mathrm{~min}$ at $37^{\circ} \mathrm{C}$. Microplates were again incubated at $37^{\circ} \mathrm{C}$ for $1 \mathrm{~h}$. Optical densities $\left(\mathrm{OD}_{550}\right)$ were determined by an ELISA reader (Bio-Tek, EL X 800). Six wells were evaluated for each compound concentration and untreated control. The percentage of viable treated cells was calculated based on untreated controls (\% of control cells $=\mathrm{OD}_{\exp } / \mathrm{OD}_{\text {control cells }} \times 100$ ). The $50 \%$ cytotoxic concentration
$\left(\mathrm{CC}_{50}\right)$ was defined as the compound concentration required to reduce the absorbance by $50 \%$ of the cell control.

\subsection{Time of addition assays}

The study was performed according to the method described by Serkedjieva and Ivancheva (1999) with some modifications. Briefly, 96-well microplates seeded with monolayers of Vero cells $\left(1 \times 10^{5}\right.$ cells/well $)$ were individually supplemented with quercetin, morin, rutin, hesperidin, cinnamic acid, trans-cinnamic acid and ferulic acid at different times based on time of infection. The first set of plates was treated for $1 \mathrm{~h}$ prior to viral infection (time $-1 \mathrm{~h}$ : pre-treatment effect). Cells were then washed twice with PBS followed by infection with serial dilutions of CDV $\left(10-10^{5}\right.$ $\mathrm{TCID}_{50} / \mathrm{mL}$ ). The second set of microplates were both infected and treated with the compounds followed by incubation at $4{ }^{\circ} \mathrm{C}$ for $1 \mathrm{~h}$ to prevent virus internalisation (time $0 \mathrm{~h}$ : adsorption effect), after which the microplates were incubated at $37^{\circ} \mathrm{C}$. The third set of plates was infected and the compounds were then added after $1 \mathrm{~h}$ adsorption at $37^{\circ} \mathrm{C}$ (time $1 \mathrm{~h}$ : penetration effect). The last set of plates was treated two hours post-infection (hpi) (time $2 \mathrm{~h}$ : intracellular effect). Assays were performed in triplicate. The antiviral activity of compounds at all stages of the viral replicativo cycle was measured by reduction in viral yield after $72 \mathrm{~h}$ post treatment compared to untreated infected cells and calculated using the method of Reed and Muench (1938). All antiviral assays were assessed under the same conditions with DMSO to evaluate the possible interference of this solvent. Ribavirin (RBV), a known positive control drug was assessed in parallel to validate the test. The $50 \%$ inhibitory concentration $\left(\mathrm{IC}_{50}\right)$ was defined as the compound concentration required to reduce viral CPE by $50 \%$ of the virus control. The selectivity index (SI) for the compounds was obtained by calculating the ratio of the $\mathrm{CC}_{50}$ and $\mathrm{IC}_{50}$ values for the virus replication at each time point.

\subsection{Evaluation of compounds structures}

Compounds were divided in two groups, flavonoids and phenolic acids, based on their characteristics and chemical properties. For each group we established the common concentration used in the time of addition assays in order to analyze their structural differences and correlated it to their antiviral activity. The following flavonoids were compared to each other at a common concentration of $30 \mu \mathrm{g} / \mathrm{mL}$ : (i) quercetin and morin, (ii) quercetin and rutin, (iii) quercetin and hesperidin, and (iv) rutin and hesperidin. For phenolic acids, a comparative analysis between (i) cinamic and trans-cinamic acids, and (ii) trans-cinamic and ferulic acids was perfomed at a concentration of $10 \mu \mathrm{g} / \mathrm{mL}$.

\subsection{Data analyses}

Statistical analyses were performed using the program Statistical Analysis and Design of Experiments - SISVAR (Sisvar 5.1 Build 72, Federal University of Lavras, MG, Brazil). Cytotoxicity and time of addition assays were analyzed by ANOVA one-way and two-way ANOVA, respectively. $\mathrm{CC}_{50}$ and $\mathrm{IC}_{50}$ were calculated from a linear regression equation. The Tukey test was used to compare means. Values of $p$ less than 0.05 were considered significant.

\section{Results}

\subsection{Cytotoxic effect}

The cytotoxicity of the evaluated compounds was determined by microscopic observation of cell morphology associated with 
the measurement of cell viability by the colorimetric method MTT. We observed that intensity and variety of cellular morphological changes (loss of monolayer, granulation, cytoplasmic vacuolisation, stretching and narrowing of the extensions as well as darkening of the cell edges) became more apparent with increasing concentrations of the compounds. Table 1 shows $\mathrm{CC}_{50}$ values obtained from the cytotoxicity assays.

DMSO $\mathrm{CC}_{50}$ was higher than the DMSO\% used to dissolve the compounds, proving the absence of DMSO cellular toxicity against Vero cells at volumes used to dissolve the compounds. The phenolic compounds showed $\mathrm{CC}_{50}$ values ranging from $115.88 \pm 11.19$ (quercetin) to $195.90 \pm 7.84 \mu \mathrm{g} / \mathrm{mL}$ (morin).

\subsection{Time of addition assays}

Antiviral activity of compounds was determined by time of addition assays. These tests had the purpose of investigating which step of the viral replicative cycle the compounds might be affecting. $\mathrm{IC}_{50}$ and $\mathrm{SI}\left(\mathrm{CC}_{50} / \mathrm{IC}_{50}\right)$ values obtained from the cytotoxicity and antiviral assays are shown in Table 1.

No significant differences were observed in viral titres with DMSO at the highest concentration $(0.8 \%)$ as a solvent for the compounds in time of addition assays (not shown data). DMSO concentrations did not interfere with antiviral activity exhibited by flavonoids and phenolic acids. A positive control with ribavirin (RBV), which affects the intracellular phase of the CDV replicative cycle, was also performed (Supplementary Fig. 1).

The IC50 and SI values of phenolic compounds exhibiting activity ranged from $3.56 \pm 0.13$ (ferulic acid, time $0 \mathrm{~h}$ ) to $40.52 \pm 1.69 \mu \mathrm{g} / \mathrm{mL}$ (morin, time $1 \mathrm{~h}$ ) and from 4.44 (transcinnamic acid, time $-1 \mathrm{~h}$ ) to 41.6 (ferulic acid, time $0 \mathrm{~h}$ ), respectively (Table 1 ).

Our results showed that all flavonoids displayed antiviral activity against CDV. As demonstrated in Fig. 1, quercetin reduced viral yield at times $0 \mathrm{~h}\left(\mathrm{EC}_{50} 11.72 \mu \mathrm{g} / \mathrm{mL}\right.$ and $\left.\mathrm{SI} 9.88\right), 1 \mathrm{~h}\left(\mathrm{EC}_{50}\right.$ $12.66 \mu \mathrm{g} / \mathrm{mL}$ and SI 9.15) and $2 \mathrm{~h}\left(\mathrm{EC}_{50} 13.94 \mu \mathrm{g} / \mathrm{mL}\right.$ and SI 9.31). Fig. 2 demonstrated that morin had antiviral effect at times $0 \mathrm{~h}$ $\left(\mathrm{EC}_{50} 34.02 \mu \mathrm{g} / \mathrm{mL}\right.$ and SI 5.76) and $1 \mathrm{~h}\left(\mathrm{EC}_{50} 40.82 \mu \mathrm{g} / \mathrm{mL}\right.$ and SI 4.83). Reduction in viral titres was most significant at the concentration of $80 \mu \mathrm{g} / \mathrm{mL}$. Rutin and hesperidin (Figs. 3 and 4) showed a significant reduction in viral infectivity at times $0 \mathrm{~h}$ (rutin: $\mathrm{EC}_{50}$ $10.41 \mu \mathrm{g} / \mathrm{mL}$ and SI 15.01; hesperidin: $\mathrm{EC}_{50} 11.09 \mu \mathrm{g} / \mathrm{mL}$ and SI 14.78) and $1 \mathrm{~h}$ (rutin: $\mathrm{EC}_{50} 13.45 \mu \mathrm{g} / \mathrm{mL}$ and SI 11.62; hesperidin: $\mathrm{EC}_{50} 13.92 \mu \mathrm{g} / \mathrm{mL}$ and SI 11.78). On the other hand, hesperidin had also shown antiviral effect at time $2 \mathrm{~h}\left(\mathrm{EC}_{50} 21.63 \mu \mathrm{g} / \mathrm{mL}\right.$ and SI 7.58) at the concentration of $30 \mu \mathrm{g} / \mathrm{mL}$. Antiviral activity exhibited by rutin and hesperidin at time $0 \mathrm{~h}$ was greater than others affecting the times 1 and $2 \mathrm{~h}$.
The three phenolic acids tested also showed inhibitory effects against CDV replication. As shown in Fig. 5, antiviral effect of cinnamic acid was demonstrated at times $0 \mathrm{~h}\left(\mathrm{EC}_{50} 4.46 \mu \mathrm{g} / \mathrm{mL}\right.$ and SI 30.12) and $2 \mathrm{~h}$ ( $\mathrm{EC}_{50} 6.18 \mu \mathrm{g} / \mathrm{mL}$ and SI 21.74), but cinnamic acid only showed a reduction in viral yield at $2 \mathrm{~h}$ only at a concentration of $10 \mu \mathrm{g} / \mathrm{mL}$. Addition of trans-cinnamic acid (Fig. 6) led to reduction of viral titres at times $-1 \mathrm{~h}\left(\mathrm{EC}_{50} 37.27 \mu \mathrm{g} / \mathrm{mL}\right.$ and SI 4.44) and $0 \mathrm{~h}\left(\mathrm{EC}_{50} 23.11 \mu \mathrm{g} / \mathrm{mL}\right.$ and SI 7.16) at the concentration of $60 \mu \mathrm{g} /$ mL. Fig. 7 shows the antiviral action of ferulic acid at times $0 \mathrm{~h}$ $\left(\mathrm{EC}_{50} 3.56 \mu \mathrm{g} / \mathrm{mL}\right.$ and SI 41.6) and $1 \mathrm{~h}\left(\mathrm{EC}_{50} 3.63 \mu \mathrm{g} / \mathrm{mL}\right.$ and SI 40.8 ), with no statistical differences between them.

\subsection{Analyses of antiviral activity versus chemical structure}

To facilitate structural evaluation of compounds related to their antiviral effects, we chose equal working concentrations for the flavonoids $(30 \mu \mathrm{g} / \mathrm{mL})$ and phenolic acids $(10 \mu \mathrm{g} / \mathrm{mL})$ in the time of addition assays. Establishment of efficient relationships between phenolic compounds was important to understand the variation of the inhibitory effects based on changes in their chemical structures. According to data presented in Table 2, flavonoids that exhibited greater antiviral activity were rutin and hesperidin, affecting the stage of adsorption; there was no significant difference between them. Quercetin and hesperidin showed inhibitory effect at almost all viral replicative cycle stages, except in the stage prior to infection. Quercetin and hesperidin were also the only flavonoids that displayed similar antiviral activity in the intracellular stage.

Among phenolic acids evaluated ferulic acid had the highest inhibitory activity against CDV in the stages of adsorption and penetration with no significant differences between them (Table 3). Cinnamic acid, on the other hand, was the only phenolic that showed inhibition in the intracellular viral stage. Trans-cinnamic acid did not show antiviral activity against CDV at the same working concentration as the other compounds.

\section{Discussion}

In the present study several flavonoids (quercetin, morin, rutin, and hesperidin) and phenolic acids (cinnamic, trans-cinnamic, and ferulic acids) were evaluated regarding their in vitro ability to inhibit stages of the CDV replicativo cycle. All flavonoids and phenolic acids demonstrated antiviral action against CDV. The observed inhibitory effects of flavonoids in the stages of adsorption and penetration suggest a direct inactivation of the virus, perhaps by binding to viral particles in an irreversible manner or by destabilizing viral ligands that are essential to the infectious process, such as envelope glycoproteins. Consequently, the role of flavonoids in

Table 1

Cytotoxicity, anti-CDV activity and selectivity indices of the tested compounds.

\begin{tabular}{|c|c|c|c|c|c|c|c|c|c|}
\hline \multirow[t]{2}{*}{ Compounds } & \multirow[t]{2}{*}{$\mathrm{CC}_{50}(\mu \mathrm{g} / \mathrm{mL})^{\mathrm{a}}$} & \multicolumn{4}{|l|}{$\begin{array}{l}\mathrm{IC}_{50}(\mu \mathrm{g} / \mathrm{mL})^{\mathrm{a}} \\
\text { Time }(\mathrm{h})^{\mathrm{c}}\end{array}$} & \multicolumn{4}{|c|}{$\begin{array}{l}\mathrm{SI}^{\mathrm{b}} \\
\text { Time }(\mathrm{h})^{\mathrm{c}}\end{array}$} \\
\hline & & -1 & 0 & 1 & 2 & -1 & 0 & 1 & 2 \\
\hline Quercetin & $115.88 \pm 11.19$ & - & $11.72 \pm 0.85$ & $12.66 \pm 1.15$ & $13.94 \pm 1.24$ & - & 9.88 & 9.15 & 8.31 \\
\hline Morin & $195.90 \pm 7.84$ & - & 34.02 & $40.52 \pm 1.69$ & - & - & 5.76 & 4.83 & - \\
\hline Rutin & $156.33 \pm 7.12$ & - & $10.41 \pm 0.12$ & $13.45 \pm 1.65$ & - & - & 15.01 & 11.62 & - \\
\hline Hesperidin & $163.99 \pm 21.09$ & - & $11.09 \pm 0.45$ & $13.92 \pm 2.2$ & $21.63 \pm 6.24$ & - & 14.78 & 11.78 & 7.58 \\
\hline Cinnamic acid & $134.37 \pm 19.08$ & - & $4.46 \pm 0.78$ & - & $6.18 \pm 1.28$ & - & 30.12 & - & 21.74 \\
\hline Trans-cinnamic acid & $165.45 \pm 13.73$ & $37.27 \pm 8.02$ & $23.11 \pm 4.48$ & - & - & 4.44 & 7.16 & - & - \\
\hline Ferulic acid & $148.11 \pm 13.47$ & - & $3.56 \pm 0.13$ & $3.63 \pm 0.08$ & - & - & 41.6 & 40.8 & - \\
\hline Ribavirin (mM) & $1.44 \pm 0.19$ & $0.05 \pm 0.01$ & - & $0.06 \pm 0.01$ & $0.03 \pm 0.01$ & 28.8 & - & 24 & 48 \\
\hline DMSO (\%) & $2.11 \pm 0.11$ & - & - & - & - & - & - & - & - \\
\hline
\end{tabular}

${ }^{\text {a }} \mathrm{CC}_{50}$ and $\mathrm{IC}_{50}$ values represent mean \pm standard error of the mean values.

b Selectivity index $\left(\mathrm{CC}_{50} / \mathrm{IC}_{50}\right)$.

c Time of addition assay. Stages of CDV replicative cycle: Pre-treatment $(-1 \mathrm{~h})$, adsorption $(0 \mathrm{~h})$, penetration ( $1 \mathrm{~h})$, and intracellular ( $2 \mathrm{~h})$. 


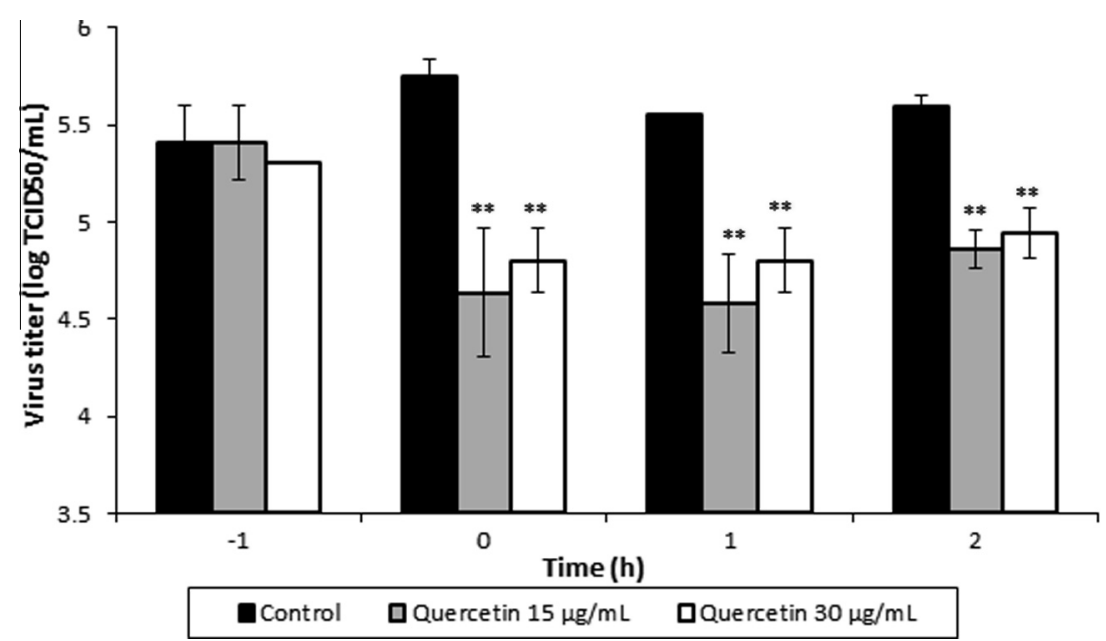

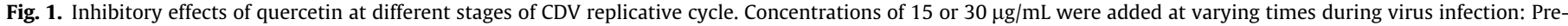
treatment $(-1 \mathrm{~h})$, adsorption $(0 \mathrm{~h})$, penetration $(1 \mathrm{~h})$, and intracellular $(2 \mathrm{~h})$. ${ }^{* *}$ Concentration is statistically different compared to untreated control $(p<0.01)$.

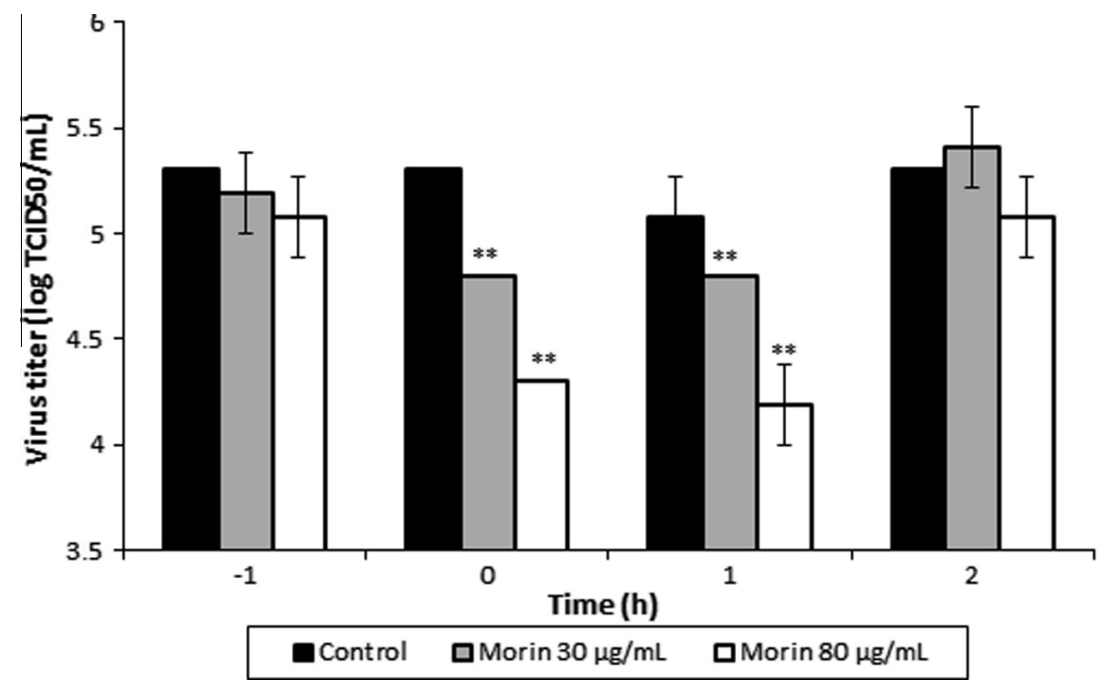

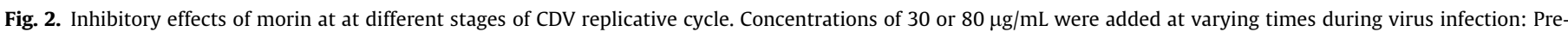
treatment $(-1 \mathrm{~h})$, adsorption $(0 \mathrm{~h})$, penetration $(1 \mathrm{~h})$, and intracellular $(2 \mathrm{~h}) .{ }^{* *}$ Concentration is statistically different compared to untreated control $(p<0.01)$.

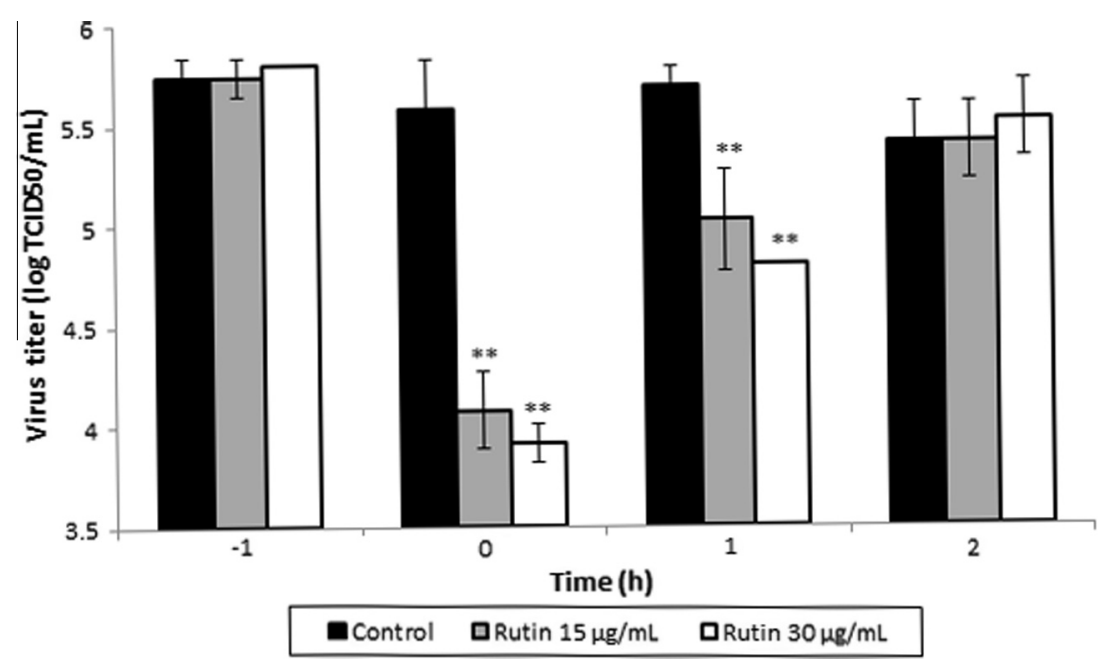

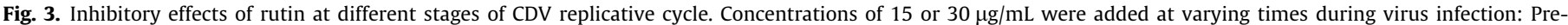
treatment $(-1 \mathrm{~h})$, adsorption $(0 \mathrm{~h})$, penetration $(1 \mathrm{~h})$, and intracellular $(2 \mathrm{~h}) .{ }^{* *}$ Concentration is statistically different compared to untreated control $(p<0.01)$. 


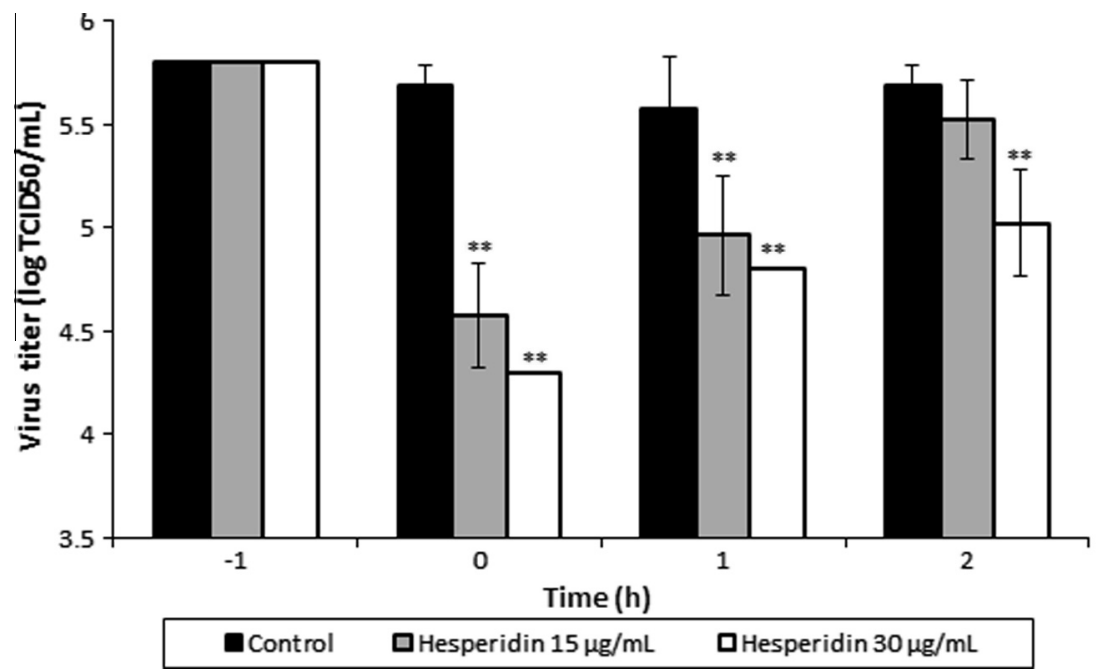

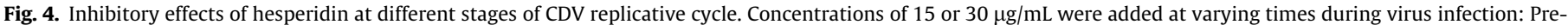
treatment $(-1 \mathrm{~h})$, adsorption $(0 \mathrm{~h})$, penetration $(1 \mathrm{~h})$, and intracellular $(2 \mathrm{~h}) .{ }^{* *}$ Concentration is statistically different compared to untreated control $(p<0.01)$.

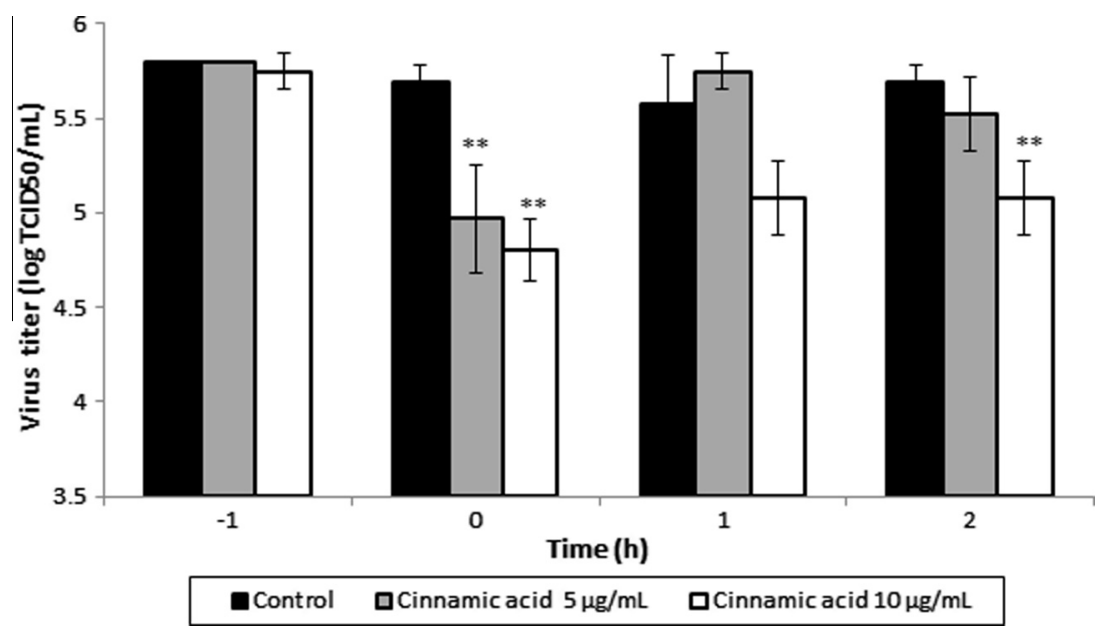

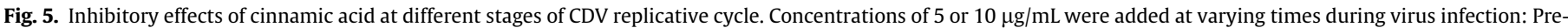
treatment $(-1 \mathrm{~h})$, adsorption $(0 \mathrm{~h})$, penetration $(1 \mathrm{~h})$, and intracellular $(2 \mathrm{~h}) .{ }^{* *}$ Concentration is statistically different compared to untreated control $(p<0.01)$.

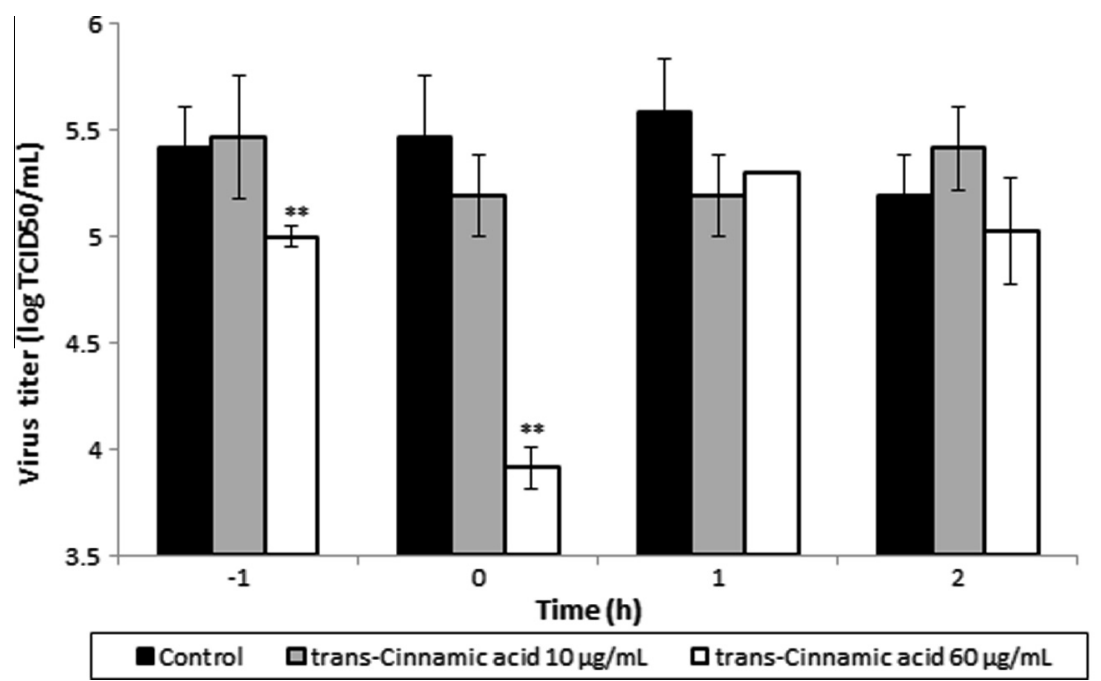

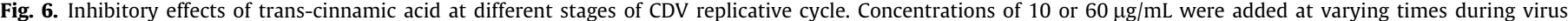

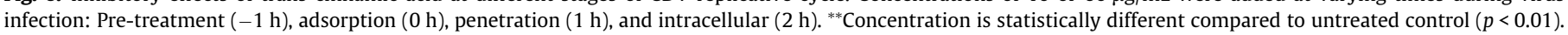




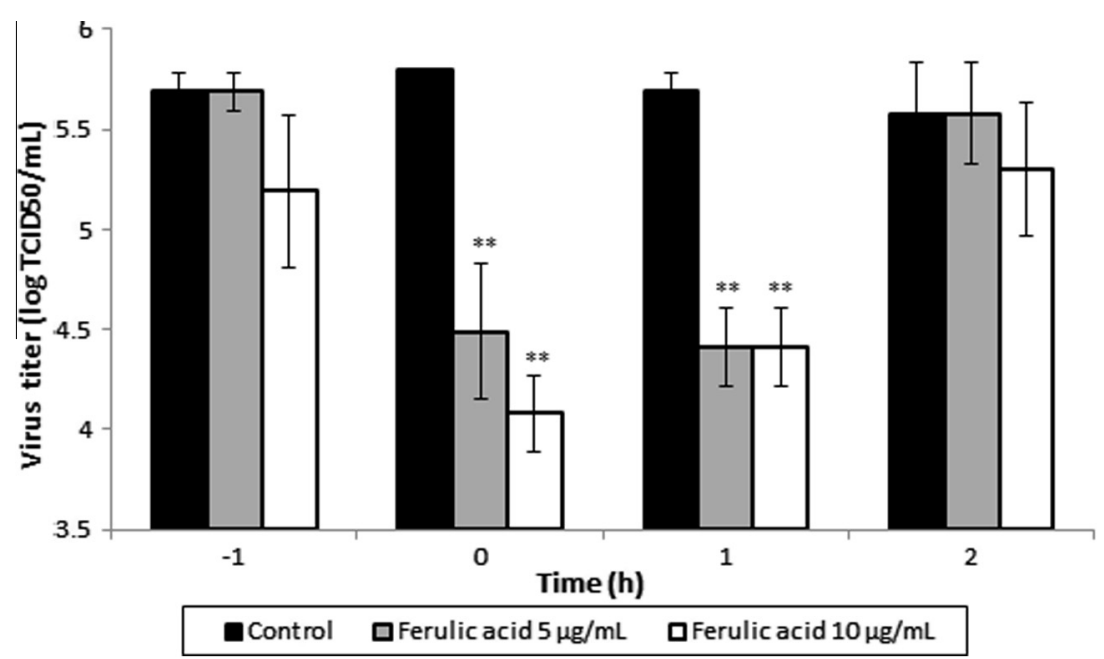

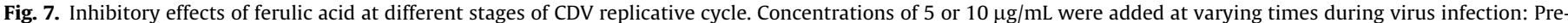
treatment $(-1 \mathrm{~h})$, adsorption $(0 \mathrm{~h})$, penetration $(1 \mathrm{~h})$, and intracellular $(2 \mathrm{~h})$. ${ }^{* *}$ Concentration is statistically different compared to untreated control $(p<0.01)$.

the early stages of viral replication would reduce the number of infected cells and the formation of viral progeny. Furthermore, selectivity index (SI) greater than 3 indicates potential antiviral activity for compounds derived from plants (Chattopadhyay et al., 2009). All phenolic compounds evaluated in the present work exhibited SI values equal or greater than 3 (Table 1 ).

Quercetin and hesperidin inhibited the intracellular phase of CDV replication cycle. It has been demonstrated that quercetin and some other flavonoids can inhibit viral polymerase and interfere with the synthesis of viral nucleic acid (Formica and Regelson, 1995; Cushnie and Lamb, 2005). Interference by such phenolic compounds in the CDV post-infection stage has also been demonstrated by Gallina et al. (2011); the phenolic dimer proanthocyanidin A2 resulted in both reduction of viral RNA synthesis and viral progeny, suggesting that the replicative complex may be affected.

On the other hand, Formica and Regelson (1995) correlated the antiviral property of quercetin with its ability to bind to envelope glycoproteins and the viral capsid. Moreover, Schnitzler et al. (2008) showed that quercetin bound to glycoproteins of the viral envelope which blocked the host cell-virus interaction. According to Kim et al. (2010) quercetin showed a reduction of influenza virus A replication in the early stages of infection. Other studies with flavonoids and tannins showed similar results at the stages of adsorption and penetration of different viruses (Kuo et al.,

Table 2

Correlation of virus titers in the positive controls (untreated) versus flavonoid treated at different stages of $\mathrm{CDV}$ replicative cycle.

\begin{tabular}{|c|c|c|c|c|c|c|}
\hline \multirow[t]{2}{*}{ Flavonoids } & \multicolumn{4}{|c|}{$\begin{array}{l}\text { Log virus titer } \mathrm{C}+/ \text { Log virus titer }[\mathrm{C}] \\
\text { Time }(\mathrm{h})\end{array}$} & \multirow[t]{2}{*}{$F$ value } & \multirow[t]{2}{*}{ CV $(\%$} \\
\hline & -1 & 0 & 1 & 2 & & \\
\hline Quercetin & $1.02^{\mathrm{aB}}$ & $1.20^{\mathrm{bA}}$ & $1.16^{\mathrm{abA}}$ & $1.13^{\mathrm{aA}}$ & $18.24^{* * *}$ & 2.78 \\
\hline Morin & $1.02^{\mathrm{aAB}}$ & $1.10^{\mathrm{bA}}$ & $1.05^{\mathrm{bAB}}$ & $0.98^{\mathrm{bB}}$ & $6.85^{*}$ & 3.22 \\
\hline Rutin & $0.99^{\mathrm{aC}}$ & $1.42^{\mathrm{aA}}$ & $1.18^{\mathrm{aB}}$ & $0.98^{\mathrm{bC}}$ & $46.47^{* * *}$ & 4.66 \\
\hline Hesperidin & $1.00^{\mathrm{aC}}$ & $1.32^{\mathrm{aA}}$ & $1.16^{\mathrm{abB}}$ & $1.13^{\mathrm{aB}}$ & $27.57^{* *}$ & 3.79 \\
\hline F value & $0.97 \mathrm{NS}$ & $35.0^{* *}$ & $5.93^{*}$ & $9.18^{* *}$ & - & - \\
\hline CV (\%) & 2.78 & 3.31 & 3.94 & 4.84 & - & - \\
\hline
\end{tabular}

Values in bold indicate significant reduction in virus titer compared to the virus control $(p<0.01)$

Averages represented by the same lower case letter (column) and upper case letter (row) did not differ by Turkey test. $\mathrm{C}+=$ untreated infected cells (positive control); $[\mathrm{C}]=$ common working concentration $(30 \mu \mathrm{g} / \mathrm{mL}) ;-1 \mathrm{~h}$ : pre-treatment; $0 \mathrm{~h}$ : adsorption; $1 \mathrm{~h}$ : penetration; $2 \mathrm{~h}$ : intracellular; NS: no significant.

* Antiviral action is statistically significant by Tukey test, $p<0.05$.

** Antiviral action is statistically significant by Tukey test, $p<0.01$.<smiles>COc1ccc(-c2oc3cc(O)cc(O)c3c(=O)c2O)c(-c2ccc(O)c(O)c2)c1O</smiles><smiles></smiles>

Fig. 8. Quercetin, morin, rutin and hesperidin chemical structures. R: sugar residue.<smiles>O=C(O)/C=C\c1ccccc1</smiles><smiles>O=C(O)/C=C/c1ccccc1</smiles>

cis-Cinnamic acid<smiles>COc1cc(/C=C/C(=O)O)ccc1O</smiles>

Fig. 9. Cis-cinnamic, trans-cinnamic and ferulic acids chemical structures.

2009; Gravina et al., 2011). The structural similarities among flavonoids might imply similar inhibitory mechanisms.

All phenolic acids evaluated in this study also demonstrated antiviral properties against CDV. Cinnamic acid derivatives have been reported to have antiviral effects against DENV (Rees et al., 2008) as well as EHV-1 in stages of pre-treatment and adsorption 
Table 3

Correlation of virus titers in the positive controls (untreated) versus phenolic acids treated at different stages of CDV replicative cycle.

\begin{tabular}{|c|c|c|c|c|c|c|}
\hline \multirow[t]{2}{*}{ Phenolic acids } & \multicolumn{4}{|c|}{$\begin{array}{l}\text { Log virus titer } \mathrm{C}+/ \text { Log virus titer }[\mathrm{C}] \\
\text { Time }(\mathrm{h})\end{array}$} & \multirow[t]{2}{*}{$F$ value } & \multirow[t]{2}{*}{$\mathrm{CV}(\%)$} \\
\hline & -1 & 0 & 1 & 2 & & \\
\hline Cinnamic acid & $1.01^{\mathrm{aB}}$ & $1.18^{\mathrm{bA}}$ & $1.10^{\mathrm{bAB}}$ & 1.11 ${ }^{\mathrm{ABB}}$ & $26.05^{* *}$ & 4.79 \\
\hline Trans-cinnamic & $0.99^{\mathrm{aA}}$ & $1.05^{\mathrm{bA}}$ & $1.07^{\mathrm{bA}}$ & $0.96^{\mathrm{bA}}$ & 2.49 NS & 5.71 \\
\hline Ferulic acid & $1.10^{\mathrm{aB}}$ & $1.45^{\mathrm{aA}}$ & $1.29^{\mathrm{aA}}$ & $1.05^{\mathrm{aB}}$ & $26.05^{* *}$ & 4.79 \\
\hline F value & $2.22 \mathrm{NS}$ & $36.32^{* *}$ & $9.28^{*}$ & $25.80^{* *}$ & - & - \\
\hline $\mathrm{CV}(\%)$ & 6.59 & 4.41 & 5.52 & 2.58 & - & - \\
\hline
\end{tabular}

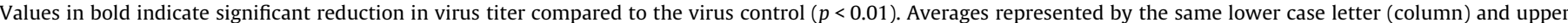

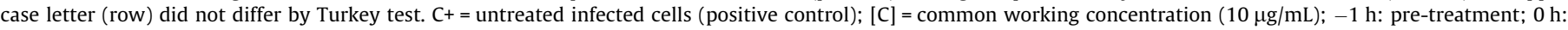
adsorption; $1 \mathrm{~h}$ : penetration; $2 \mathrm{~h}$ : intracellular; NS: no significant.

* Antiviral action is statistically significant by Tukey test, $p<0.05$.

** Antiviral action is statistically significant by Tukey test, $p<0.01$.

(Gravina et al., 2011). This antiviral action may be due to a direct action to inactivate viral particles and/or cellular receptors, perhaps leading to their destabilization or blocking virus-cell interaction.

Cinnamic acid is a precursor in the synthesis of flavonoids and other phenolic acids, demonstrating a positive correlation between phenolic structures and antiviral properties. Phenolic compounds are reported to have high affinity for proteins, forming unstable complexes (Haslam, 1996). Therefore, the antiviral effects of flavonoids in the early and post-infectious stages of CDV cycle can be applied to phenolic acids which have inhibitory mechanisms through interaction with viral envelope glycoproteins (Schnitzler et al., 2008), or inhibition of viral polymerase with consequent interference in viral genome synthesis(Formica and Regelson, 1995; Cushnie and Lamb, 2005).

In this study, we also analyzed the structural differences among compounds in order to investigate whether it was correlated with antiviral activity which might be useful for the design of new antiviral drugs. The structural similarity between quercetin and morin may be related to the results observed in our study since they were able to inhibit the stages of adsorption and penetration (Table 2, Fig. 8). Both flavonoids belong to the flavonol class and the only structural difference between them is the hydroxyl position in ring $\mathrm{B}$; morin has hydroxyls at C-2' and C-4' (meta), quercetin at C-3' and $\mathrm{C}-4^{\prime}$ (ortho). Thus, absence of antiviral action in the postinfection phases for morin might be related to the position of the hydroxyl at $C-2^{\prime}$, which might prevent its biological effects on CDV.

Rutin, another flavanol, also has a chemical structure similar to quercetin; however, it is glycosylated in the $\mathrm{C}-3$ position of the ring $\mathrm{C}$ (Fig. 8). It is still unclear how these flavonoids specifically act, but this structural difference between the two might have contributed to the antiviral effect of rutin in the adsorption stage which was greater than that of quercetin.

Hesperidin is classified in the flavonones class due to the absence of a double bond between C-2 and C-3 in ring C. Similar to quercetin, it also presents substitutes in the same positions of ring $\mathrm{B}\left(\mathrm{C}-3^{\prime}\right.$ and $\left.\mathrm{C}-4^{\prime}\right)$, but hesperidin is glycosylated at the hydroxyl of C-7 in ring A (Fig. 8). Although the structural similarity explains the inhibitory effects, which were statistically identical for penetration and intracellular replication, the sugar existent in the hesperidin might be responsible for the greater antiviral activity compared to quercetin in the adsorption step.

When comparing rutin and hesperidin, both have ortho substitutions in positions $C-3^{\prime}$ and $C-4^{\prime}$ in ring $B$ and antiviral effects at the stages of adsorption and penetration (Fig. 8). The difference in the structural sugar insertion for these two flavonoids might be related to the intracellular viral inhibition stage. Since this inhibition was observed only for hesperidin it is possible that the antiviral mechanism is related to the position of the sugar in the C-7 hydroxyl of ring A. The greatest antiviral activity was demonstrated for the glycosylated flavonoids in the stage of adsorption, suggesting that the sugar present in the polyphenolic compounds had more affinity to bind to viral structures important to the onset of infection.

Phenolic acids evaluated in our study also possess considerable structural similarity. Cinnamic and trans-cinnamic acids are geometrical isomers; however, the trans isomer form lacked antiviral effect since trans-cinnamic acid did not present antiviral action at the lowest working concentration (Table 3, Fig. 9). On the other hand, the cis isomer form of cinnamic acid provided interference in the stages of adsorption and intracellular viral replicative cycle. Ferulic acid differs from trans-cinnamic acid only by the presence of substitutes in C- 4 and C-5 of the aromatic ring, and these structural differences might be related to the antiviral effects in the stages of adsorption and penetration compared to trans-cinnamic acid. Structural differences of ferulic acid in relation to trans-cinnamic acid might be responsible for an increase in its affinity for cellular receptors and/or viral fusion proteins, which would also amplify its inhibitory mechanism during the viral adsorption phase. Our results showed that ferulic acid exhibited the greatest antiviral activity when compared to cinnamic acid.

Phenolic compounds evaluated here revealed significant antiviral activity against CDV. Further analysis will determine whether those promising candidates can be considered in the treatment of CDV as well as for the development of antiviral drugs against other viruses of significance in veterinary medicine such as measles virus, since both are genetically related (Summers and Appel, 1994; Rudd et al., 2006; Rodeheffer et al., 2007). Our analysis of the relationship between chemical structures of compounds and their antiviral activities may indicate putative sites that might be used as models for designing new antiviral agents. Future experiments are still required to determine the inhibitory mechanism displayed by flavonoids and phenolic acids in order to assess their applicability in the treatment of CDV-infected animals.

\section{Conflict of interest}

None of the authors has any financial or personal relationships that could inappropriately influence or bias the content of the paper.

\section{Acknowledgements}

The authors would like to thank FAPEMIG (Fundação de Amparo à Pesquisa do Estado de Minas Gerais), FUNARBE (Fundação de Apoio à Universidade Federal de Viçosa) and CNPq (Conselho Nac- 
ional de Desenvolvimento Científico e Tecnológico) for the financial support of this research.

\section{Appendix A. Supplementary data}

Supplementary data associated with this article can be found, in the online version, at http://dx.doi.org/10.1016/j.rvsc.2013.04.013.

\section{References}

Appel, M.J.G., Yates, R.A., Foley, G.L., 1994. Canine distemper epizootic in lions, tigers and leopards in North America. Journal of Veterinary Diagnostic Investigation 6, 277-288.

Bagla, V.P., McGaw, L.J., Eloff, J.N., 2012. The antiviral activity of six South African plants traditionally used against infections in ethnoveterinary medicine. Veterinary Microbiology 155, 198-206.

Chattopadhyay, D., Chawla-Sarkar, M., Chatterjee, T., Dey, R.S., Bag, P., Chakraborti, S., Khan, M.R.H., 2009. Recent advancements for the evaluation of anti-viral activities of natural products. New Biotechnology 25 (5), 347-368.

Choi, H.J., Kim, J.H., Lee, C.H., Ahn, Y.J., Song, J.H., Baek, S.H., Kwon, D.H., 2009. Antiviral activity of quercetin 7-rhamnoside against porcine epidemic. Antiviral Research 81 (1), 77-80.

Cushnie, T.P., Lamb, A.J., 2005. Antimicrobial activity of flavonoids. International Journal of Antimicrobial Agents 26, 343-356.

Dal Pozzo, F., Galligioni, V., Vaccari, F., Gallina, L., Battilani, M., Scagliarini, A., 2010. Antiviral efficacy of EICAR against canine distemper virus (CDV) in vitro. Research in Veterinary Science 88, 339-344.

Elia, G., Belloli, C., Cirone, F., Lucente, M.S., Caruso, M., Martella, V., Decaro, N., Buonavoglia, C., Ormas, P., 2008. In vitro efficacy of ribavirin against canine distemper virus. Antiviral Research 77, 108-113.

Formica, J.V., Regelson, W., 1995. Review of biology of quercetin and related bioflavanoids. Food and Chemical Toxicology 33, 1061-1080.

Gallina, L.Dal., Pozzo, F., Galligioni, V., Bombardelli, E., Scagliarinni, A., 2011. Inhibition of viral RNA synthesis in canine distemper virus infection by proanthocyanidin A2. Antiviral Research 92, 447-452.

Gravina, H.D., Tafuri, N.F., Silva Júnior, A., Fietto, J.L.R., Oliveira, T.T., Diaz, M.A.N., Almeida, R., 2011. In vitro assessment of the antiviral potential of transcinnamic acid, quercetina and morin against equid herpesvirus 1 . Research in Veterinary Science 91 (3), 158-162.

Haslam, E., 1996. Natural polyphenols (vegetable tannins) as drugs: possible modes of action. Journal of Natural Products 59, 205-215.

Ichimura, T., Otake, T., Mori, H., Maruyama, S., 1999. HIV-1 protease inhibition and anti-HIV effect and natural and synthetic water-soluble lignin-like substances. Bioscience, Biotechnology, and Biochemistry 63 (12), 2202-2204.

Kennedy, S., 1998. Morbillivirus infections in marine mammals. Journal of Comparative Pathology 25, 119-201.

Kim, Y., Narayanan, S., Chang, K., 2010. Inhibition of influenza virus replication by plant-derived isoquercetin. Antiviral Research 88, 227-235.

Kuo, K., Chang, J., Wang, K., Chiang, L., 2009. Water extract of Glycyrrhiza uralensis inhibited enterovirus 71 in a human foreskin fibroblast cell line. American Journal of Chinese Medicine 37, 383-394.

Martella, V., Elia, G., Buonavoglia, C., 2008. Canine distemper virus. The Veterinary Clinics of North America: Small Animal Practice 38, 787-797.

Moro, L., Alves, M., Alves, F., Santos, F.G.A., Martins, A.S, Vasconcelos, A.C, 2004. Apoptose na desmielinização da cinomose canina (Revisão da literatura). Bioscience Journal 20, 171-178.
Mosmann, T., 1983. Rapid colorimetric assay for cellular growth and survival: application to proliferation and cytotoxicity assays. Journal of Immunological Methods 65, 55-63.

Murphy, F.A., Gibbs, E.P.J., Horzinek, M.C., Studdert, M.J., 1999. Veterinary Virology. Academic Press, San Diego, USA, 629 pp.

Nafisi, S., Hashemi, M., Rajabi, M., Riah, T.H.A., 2008. DNA adducts with antioxidant flavonoids: morin, apigenin, and naringin. DNA and Cell Biology 27, 1-10.

Orhan, D.D., Özçelic, B., Özgen, S., Ergun, F., 2010. Antibacterial, antifungal, and antiviral activities of some flavonoids. Microbiological Research 165, 496504.

Reed, L., Muench, H., 1938. A simple method of estimating fifty percent endpoints American Journal of Tropical Medicine and Hygiene 18, 493-494.

Rees, C.R., Costin, J.M., Fink, R.C., McMichael, M., Fontaine, S.I., Michael, S.F., 2008. In vitro inhibition of dengue virus entry by p-sulfoxy-cinnamic acid and structurally related combinatorial chemistries. Antiviral Research 80, 135-142.

Rodeheffer, C., Von Messling, V., Milot, S., Lepine, F., Manges, A.M., Ward, B.J., 2007. Disease manifestations of canine distemper virus infection in ferrets are modulated by vitamin A status. The Journal of Nutrition 137, 1916-1922.

Rudd, P.A. Cattaneo, R., Von Messling, V., 2006. Canine distemper virus uses both the anterograde and the hematogenous pathway for neuroinvasion. Journal of Virology 80 (19), 9361-9370.

Saha, R.K., Takahashi, T., Suzuki, T., 2009. Glucosyl hesperidin prevents influenza a virus replication in vitro by inhibition of viral sialidase repon. Biological and Pharmaceutical Bulletin 32 (7), 1188-1192.

Scagliarini, A., Vaccari, F., Gallina, L., Vaccari, F., Dal Pozzo, F., Prosperi, S., 2006. In vitro evaluation of antiviral activity of ribavirin against canine distemper virus. Veterinary Research Communications 30 (Suppl 1), 269-272.

Schnitzler, P., Nolkemper, S., Stintzing, F.C., Reichling, J., 2008. Comparative In vitro Study on the Anti-Herpetic effect of phytochemically chacarterized aqueous and ethanolic extracts of Salvia officinalis grown at two different locations. Phytomedicine 15, 62-70.

Serkedjieva, J., Ivancheva, S., 1999. Antiherpes virus of extracts from the medicinal plant Geranium sanguineum L. Journal of Ethnopharmacology 64, 59-68.

Shimosaki, S., Tsurunaga, Y., Itamura, H., Nakamura, M., 2011. Anti-allergic effect of the flavonoid myricitrin from Myrica rubra leaf extracts in vitro and in vivo. Natural Products Research 25 (4), 374-380.

Shon, M., Choi, S., Kahng, G., Nam, S., Sung, N., 2004. Antimutagenic, antioxidant and free radical scavenging activity of ethyl acetate extracts from white, yellow and red onions. Food and Chemical Toxicology 42 (4), 659-666.

Summers, B.A., Appel, M.J., 1994. Aspects of canine distemper virus and measles virus encephalomyelitis. Neuropathology and Applied Neurobiology 20, 525534.

Tao, J., Hu, Q., Yang, J., Li, R., Li, X., Lu, C., Chene, C., Wang, L., Shattock, R., Ben, K. 2007. In vitro anti-HIV and -HSV activity and safety of sodium rutin sulfate as a microbicide candidate. Antiviral Research 75, 227-233.

Thapa, M., Kim, Y., Desper, J., Chang, K., Hua, D.H., 2011. Synthesis and antiviral activity of substituted quercetins. Bioorganic \& Medicinal Chemistry Letters.

White, L.K., Yoon, J.J., Lee, J.K., Sun, A., Du, Y., Fu, H., Snyder, J.P., Plemper, R.K., 2007. Nonnucleoside inhibitor of measles virus RNA-dependent RNA polymerase complex activity. Antimicrobial Agents and Chemotherapy 51, 2293-2303.

Yadav, P., Mohan, H., Maity, D.K., Suresh, C.H., Rao, B.S.M., 2008. Oxidation of cinnamic acid derivatives: a pulse radiolysis and theoretical study. Chemical Physics 351, 57-64.

Yoon, J.J., Chawla, D., Paal, T., Ndungu, M., Du, Y., Kurtkaya, S., Sun, A., Snyder, J.P., Plemper, R.K., 2008. High-throughput screening-based identification of paramyxovirus inhibitors. Journal of Biomolecular Screening 13, 591-608.

Zandi, K., Teoh, B., Sam, S., Wong, P., Mustafa, M., AbuBakar, S., 2011. In vitro antiviral activity of fisetin, rutin and naringenin against dengue virus type-2. Journal of Medicinal Plants Research 4 (23), 5534-5539. 